\title{
MODEL PENDAMPINGAN LANJUT USIA PENYINTAS COVID-19
}

\author{
Wahyudin Darmalaksana \\ Fakultas Ushuluddin UIN Sunan Gunung Djati Bandung, e-mail : yudi_darma@uinsgd.ac.id
}

\begin{abstract}
Abstrak
Penyintas Covid-19 lanjut usia sering mengalami gangguan kesehatan yang cukup serius, sehingga dibutuhkan perhatian dan penangan yang serius pula. Pengabdian ini bertujuan untuk melaksanakan model pendampingan bagi lanjut usia penyintas Covid-19. Metode pengabdian ini menggunakan participation action research. Hasil pengabdian menunjukan bahwa keberhasilan dapat dicapai melalui penerapan model pendampingan lanjut usia penyintas Covid-19. Penerapan model ini dimulai sejak refleksi sosial, perencanaan partisipatif, dan hingga pelaksanaan program. Keberhasilan pengabdian ini dilihat dari indikator kemajuan kesehatan terhadap tiga orang lannjut usia penyintas Covid-19. Adapun indikator kesehatan meliputi timbulnya motivasi pemulihan dari dalam diri para penyintas Covid-19, dilihat dari kondisi kesehatan fisik dan mental yang terus berangsur baik, dan keterangan medis dari bidang kedokteran. Pengabdian ini menyimpulkan bahwa model pendampingan memiliki kekuatan yang efisien bagi pemulihan kesehatan lanjut usia penyintas Covid-19.
\end{abstract}

Kata Kunci: Covid-19, lanjut usia, partisipatoris

\begin{abstract}
Elderly Covid-19 survivors often experience serious health problems, so serious attention and handling are needed as well. This service aims to implement a model of mentoring for elderly Covid-19 survivors. This dedication method uses participation action research. The results of the service show that success can be achieved through the application of a model for assisting elderly Covid-19 survivors. The application of this model starts from social reflection, participatory planning, and to program implementation. The success of this service can be seen from the indicators of health progress for three elderly Covid-19 survivors. The health indicators include the emergence of motivation for recovery from within the Covid-19 survivors, seen from physical and mental health conditions that continue to improve, and medical information from the medical field. This service concludes that the mentoring model has efficient power for the recovery of the health of elderly Covid-19 survivors.
\end{abstract}

Keywords: Covid-19, elderly, participatory

\section{PENDAHULUAN}

Pemulihan kondisi kesehatan bagi penyintas Covid-19 dibutuhkan penanganan yang cukup serius. Meskipun telah dinyatakan negatif, namun diketahui beberapa orang penyintas Covid-19 mengeluhkan kondisi tubuh yang belum normal. Kenyataan ini terlebih lagi dialami oleh penderita dengan lanjut usia, lansia (Rizaldi and Rahmasari 2021).

Baru-baru ini di Indonesia berlangsung sitausi darurat Covid-19, hal ini ditandai dengan eskalasi peningkatan paparan virus Covid-19, terutama dimulai akhir Juni 2021. Mengingat situasi dan kondisi darurat Covid-19 sehingga pemerintah Indonesia menetapkan kebijakan tentang pemberlakukan pembatasan kegiatan masyarakat yang dikenal PPKM (Darmalaksana 2021). Dalam situasi darurat ini kerap dijumpai beberapa warga terpapar pandemi Covid-19 dan mereka sangat membutuhkan uluran bantuan pihak-pihak terkait. Praktis, situasi ini telah menuntut semua pihak untuk memiliki kepedulian dalam bentuk apapun yang dapat dilakaukan. Semua pihak dituntut tegerak terjun membantu arga masyarakat yang terpapar virus Covid-19. Tentu saja berbagai aktivitas harus tetap memperhatikan dan mematuhi protokol kesehatan yang biasa disingkat prokes (Irmayani et al. 2021).

Informasi terkait paparan Covid-19 di warga masyarakat dengan mudah dapat ditemukan dari data paling mutakhir pemerintahan daerah setempat. Data 
menunjukan bahwa beberapa warga merupakan penyintas Covid-19 dan di antara mereka merupakan lansia. Diketahui bahwa lansia termasuk kelompok yang paling rentan terhadap paparan Covid-19. Meskipun merupakan kategori penyintas, namun mereka sangat membutuhkan perhatian serius dalam pemulihan kondisi kesehatan pasca terpapar Covid19 (Syahruddin 2020).

Covid-19 sangat rentan bagi lansia 60 tahun ke atas. Hal ini akibat melemahnya kekebalan, imunitas, dan atau daya tahan tubuh (Tobing and Wulandari 2021). Sejumlah kasus lansia tetap harus menjalani pengobatan, meskipun mereka selamat dari Covid19. Oleh karena itu, peneliti tertarik untuk melakukan pengabdian secara partisipatoris pada lansia penyintas Covid-19. Dengan demikian, tujuan penelitian atau pengabdian ini adalah partisipasi masyarakat melalui model pendampingan pada lansia penyintas Covid-19.

Obat virus Covid-19 belum ditemukan di dunia ini. Orang sembuh dari Covid-19 terutama karena imunitas tubuh (Amalia and Hiola 2020). Sehingga asupan vitamin (Hermawan 2021) dan berjemur matahari (Mexitalia et al. 2020) sangat dianjurkan di masa pandemi Covid-19. Juga bantuan psikologis berperan sangat besar bagi kesehatan mental (Purwoko and Sartinah 2021). Beberapa pihak menyatakan bahwa terapi spriritual diakui cukup efektif dalam mengatasi kecemasan akibat pandemi Covid-19 (Chodijah et al. 2020; Yono, Rusmana, and Noviyanty 2020). Bagi umat beragama, justru pendekatan agama tidak bisa dilepaskan dalam menghadapi pandemi Covid-19 (Muhammad Tahir 2020). Dalam hal ini, Covid-19 bukan hanya masalah medis, melainkan juga tantangan kaum beriman dari sisi agama (Supriatna 2020). Covid-19 niscaya harus ditangani secara medis dari dunia kedokteran dan kesehatan (Widjanantie et al. 2020) melalui penanganan secara profesional dari dokter dan tenaga kesehatan, yang lazim disingkat nakes. Meskipun pasti dokter dan nakes sendiri dalam situasi darurat Covid-19 memiliki keterbatasan (Rosyanti and Hadi 2020). Sejalan dengan ini, bimbingan agama (Islam) jelas memiliki peran yang sangat penting (Suud et al. 2020). Dan bahkan, semua pihak dituntut memberika partisipasi dalam penanganan penyebaran Covid-19 di tengah-tengah warga masyarakat (Mulyadi 2020). Terlebih lagi pengendalian dan penanganan serta pemulihan Covid-19 bagi lansia (Hartutik and Nurrohmah 2021), mekipun mereka merupakan penyintas (Rizaldi and Rahmasari 2021), yakni orang yang dinyatakan selamat dari Covid-19.

\section{METODOLOGI PENGABDIAN}

Pengabdian ini menggunakan pendekatan dan metode yang telah populer diterapkan dalam agenda partisipasi masyarakat, yakni participation action research yang biasa disingkat PAR. Metode ini mengarahkan peneliti agar berupaya terhubung dengan agenda perubahan di tengah-tengah masyarakat dalam menciptakan kondisi yang diharapkan melalui partisipasi warga secara aktif (Rahmat and Mirnawati 2020).

Agenda pengabdian ini berusaha dengan Bersama-sama warga menemukan model pendampingan untuk pemulihan kesehatan bagi lansia penyintas Covid-19. Di dalam agenda ini ditetapkan dua hal, yaitu 1) rancangan kegiatan dan 2) rancangan evaluasi. Pertama, rancangan kegiatan disusun sejak refleksi sosial, perencanaan partisipatif, dan hingga pelaksanaan program. Kedua, rancangan evaluasi disusun berkaitan dengan indikator-indikator keberhasilan serta alat ukur yang menentukan keberhasilan, baik pada unit-unit kecil pelaksanaan kegitan maupun pada seluruh pelaksanaan pengabdian kepada masyarakat secara partisipatoris, khususnya dalam upaya menemukan model realisasi pendampingan lansia penyintas Covid-19.

Tempat pelaksanaan pengabdian masyarakat ini dilaksankan di Kampung Cigendel Desa Pamulihan Kecamatan Tanjungsari Kabubaten Sumedang, Jawa Barat. Sedangkan waktu pelaksanan pengabdian berlangsung tanggal 19 Juli 2021 sampai 12 Agustus 2021.

\section{PELAKSANAAN KEGIATAN}

Pelaksanaan kegiatan pengabdian meliputi tiga hal utama, yakni refleksi sosial, perencanaan partisipatif, dan pelaksanaan program.

\section{Refleksi Sosial}

Mula-mula dilakukan refleksi sosial (social reflection), yaitu proses interaksi yang dilakukan masyarakat untuk membaca konsep dan identitas diri masyarakat dengan ekspektasi teridentifikasinya 
kebutuhan, masalah, potensi, dan atau asset kelompok masyarakat itu.

Tabel 1. Penyintas Covid-19

\begin{tabular}{cccc} 
No. & Gender & Usia & Status \\
\hline 1 & $\mathrm{P}$ & 85 & Penyintas \\
\hline 2 & $\mathrm{~L}$ & 76 & Penyintas \\
\hline 3 & $\mathrm{P}$ & 69 & Penyintas \\
\hline
\end{tabular}

Tabel 1 merupakan subjek lansia penyintas Covid-19, yaitu perempuan (P) usia 85 tahun, lakilaki (L) usia 76 tahun, dan perempuan (P) 69 tahun. Diperoleh keterangan bahwa ketiganya dinyatakan positif pada hari Minggu, 04 Juli 2021 dan dinyatakan negatif pada hari Senin, 19 Juli 2021.

Pasca dinyatakan negatif dijumpai bahwa para penyintas Covid-19 tampak ketiganya masih membutuhkan pemulihan kesehatan. Mereka masih mengalami kondisi tubuh yang belum stabil. Tubuh dirasakan masih lemas, mudah pusing, terkadang timbul demam, dan selera makan belum normal. Bahkan, P usia 69 tahun ada indikasi mesti dibawa ke rumah sakit untuk dilakukan pemeriksaan dokter mengingat terkendala asupan makanan.

Adapun pontensi besar adalah ketiganya merupakan penganut Islam yang dinilai taat menjalankan amalan Islam. Juga merupakan potensi besar lainnya ialah ketiganya memiliki semangat berupa motivasi dari dalam diri untuk segera pulih dan sembuh. Potensi lainnya yaitu dukungan dari anggota keluarga yang terus mengalir serta dukungan tenaga kesehatan dan warga sekitar. Termasuk ke dalam potensi di sini yakni lingkungan fisik yang mendukung bagi terwujudnya pemulihan.

\section{Perencanaan Partisipatif}

Partisipatif di sini bermakna keterlibatan peneliti bersama stakeholders di dalam warga masyarakat, yang dalam hal ini meliputi petugas kesehatan Covid di daerah setempat, penyintas Covid-19 sendiri, dan anggota keluarga besar penyintas Covid-19. Partisipasi dimaksudkan sebagai upaya untuk menciptakan sinergi program dalam model pendampingan lansia penyintas Covid-19.

Sejumlah perencanaan partisipatif dirancang. Pertama, penggalian informasi terkait kesehatan Covid-19, petunjuk pemulihan terkhusus untuk lansia, hearing, dan konsultasi berbagai hal penting kepada tenaga ahli kesehatan dari petugas pengendalian Covid-19 di pemerintah daerah setempat. Kedua, mendengarkan ide-ide dan pandangan anggota keluarga besar tentang program pendampingan pemulihan kesehatan bagi lansia penyintas Covid-19. Terakhir, ketiga, penyusunan rencana kegiatan pendampingan pemulihan kesehatan bagi para lansia penyintas Covid-19.

Ada beberapa rencana program kegiatan yang dihasilkan. Pertama, pemeriksaan kondisi kesehatan penyintas Covid-19 melalui medis oleh dokter di rumah sakit. Kedua, perawatan dan pemulihan penyintas Covid-19 sesuai ajuran dokter. Ketiga, agenda rutin pengendalian dan penanganan harian meliputi upaya menjaga keteraturan asupan gizi dan vitamin, cek saturasi oksigen, berjemur terik matahari di pagi hari, konseling, dan relaksasi.

Direncanakan pula agenda evaluasi model pendampingan lansia penyintas Covid-19. Hal ini berupa kontrol pemulihan dengan indikator-indikator kemajuan kesehatan. Sedangkan target dari evaluasi ini berupa harapan para penyintas Covid-19 benarbenar kesehatan mereka dinyatakan pulih.

\section{Pelaksanaan Program}

Pendampingan lansia penyintas Covid-19 ini merupakan agenda lanjutan. Pada awalnya dimulai tanggal 04-19 Juli 2021 dan dilanjutkan sampai Agustus 2021.

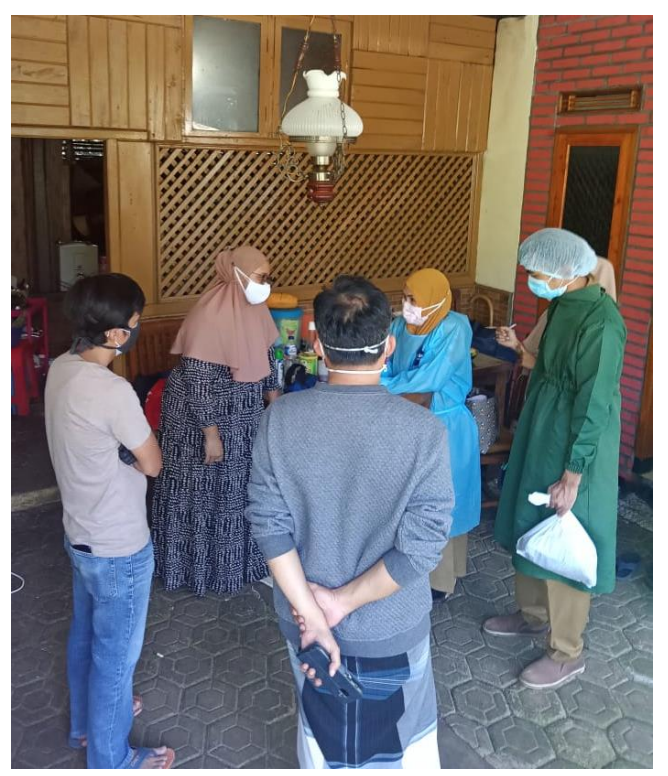

Gambar 2. Konsultasi Tenaga Kesehatan 
Gambar 2 merupakan paparan dalam agenda konsultasi dari tenaga kesehatan daerah setempat. Dari peristiwa ini diperoleh informasi tentang pencegahan, pengendalian, peanganan, dan pemulihan sesuai dengan prokes Covid-19. Diperoleh juga arahan dan pentunjuk tentang pengurusan administrasi untuk warga yang terpapar Covid-19 sesuai prosedur yang berlaku dan diterapkan pada pemerintahan daerah setempat.

Tenaga kesehatan Covid-19 di daerah setempat memiliki beberapa tugas. Antara lain pendataan orang terpapar Covid-19, melakukan penyuluhan terkait dengan prokes Covid-19, memberikan bimbingan konseling bagi individu yang terpapar Covid-19, dan memberikan rujukan bagi pengobatan di Puskesmas. Hal yang ditekankan ialah menjaga imun, menjaga jarak, mencuci tangan, menggunakan masker, dan lain-lain.

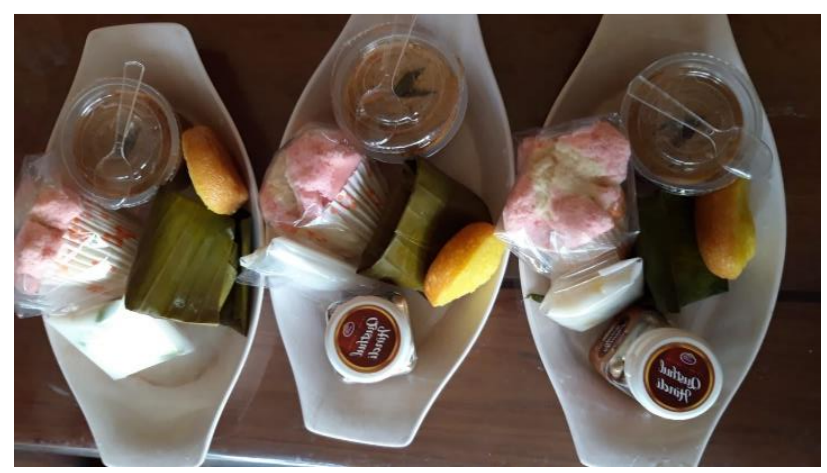

Gambar 3. Asupan Penyintas Covid-19

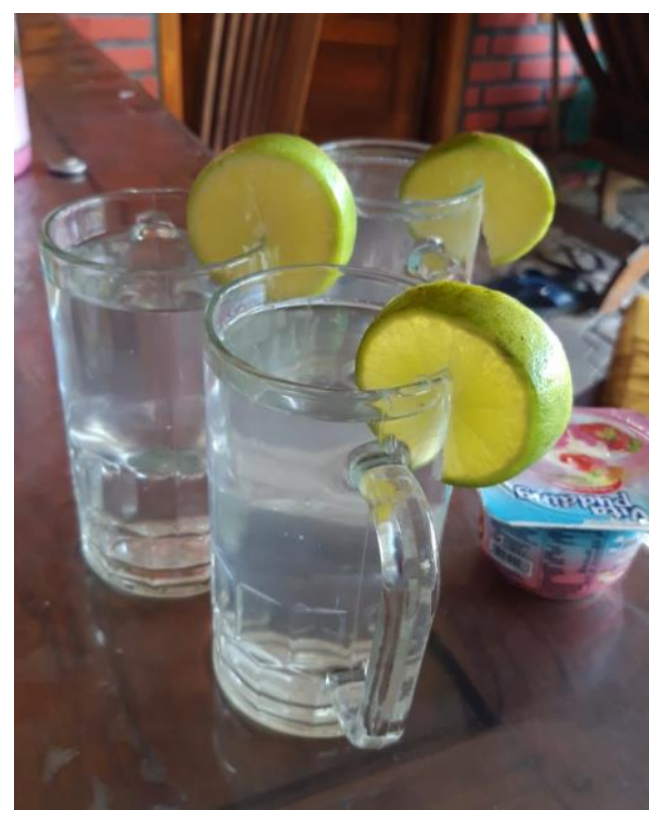

Gambar 4. Minuman Penyintas Covid-19
Gambar 3 merupakan salah satu jenis asupan makanan yang disiapkan untuk lansia penyintas Covid-19. Berupa kue-kue basah jajanan pasar dan herbal untuk meningkatkan imun dalam tubuh penyintas Covid-19.

Gambar 4 adalah minuman vitamin berupa air kepala muda dengan larutan air jeruk lemon. Minuman ini disajikan juga untuk meningkatkan imun penyintas Covid-19. Selainnya, secara bervariasi disajikan pula minuman dan vitamin jenisjenis lain.

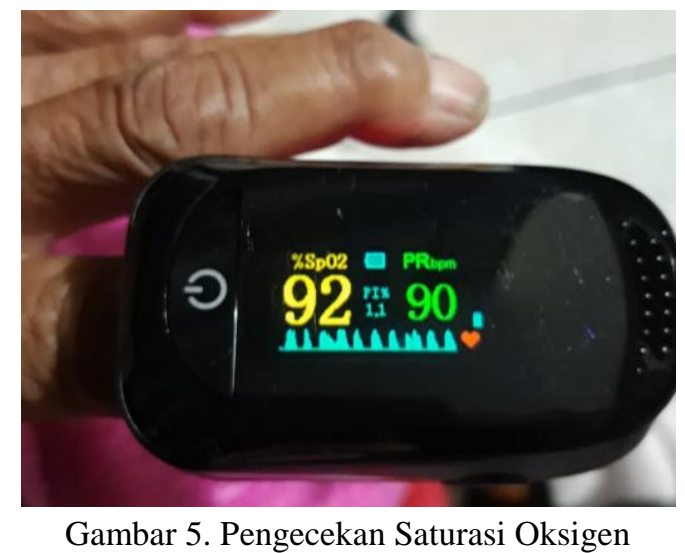

Gambar 5 ialah pengecekan saturasi oksigen. Diketahui bahwa ukuran normal adalah di atas 90 . Jika di bawah itu maka menunjukan adanya ganggungan pernafasan yang biasanya disertai sesak nafas. Hingga pada beberapa orang dibutuhkan tabung oksigen untuk kelancaran pernafasan. Pengecekan saturasi oksigen dilakukan secara berkala untuk memantau dan menjaga hal-hal yang tidak diharapkan.

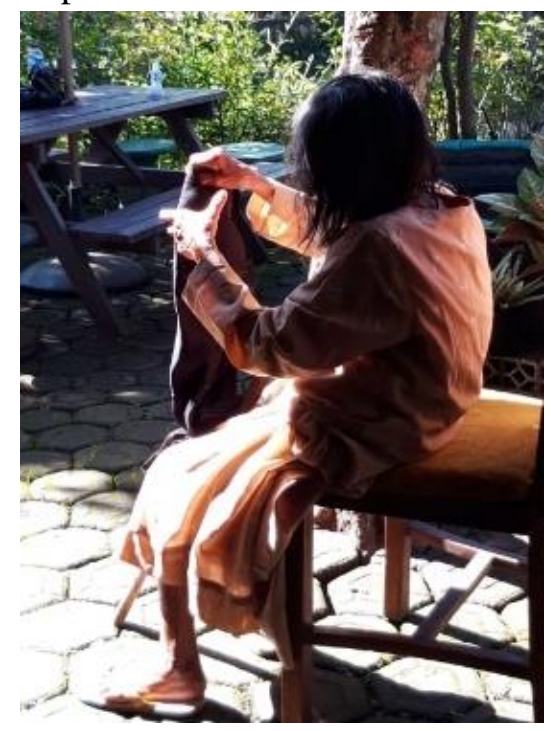

Gambar 6. Berjemur Terik Matahari 
Gambar 6 merupakan agenda rutin pada pagi hari mulai sekitar pukul 09-11 WIB. untuk berjemur terik matahari. Tampak pada Gambar 6 adalah P usia 85 tahun.

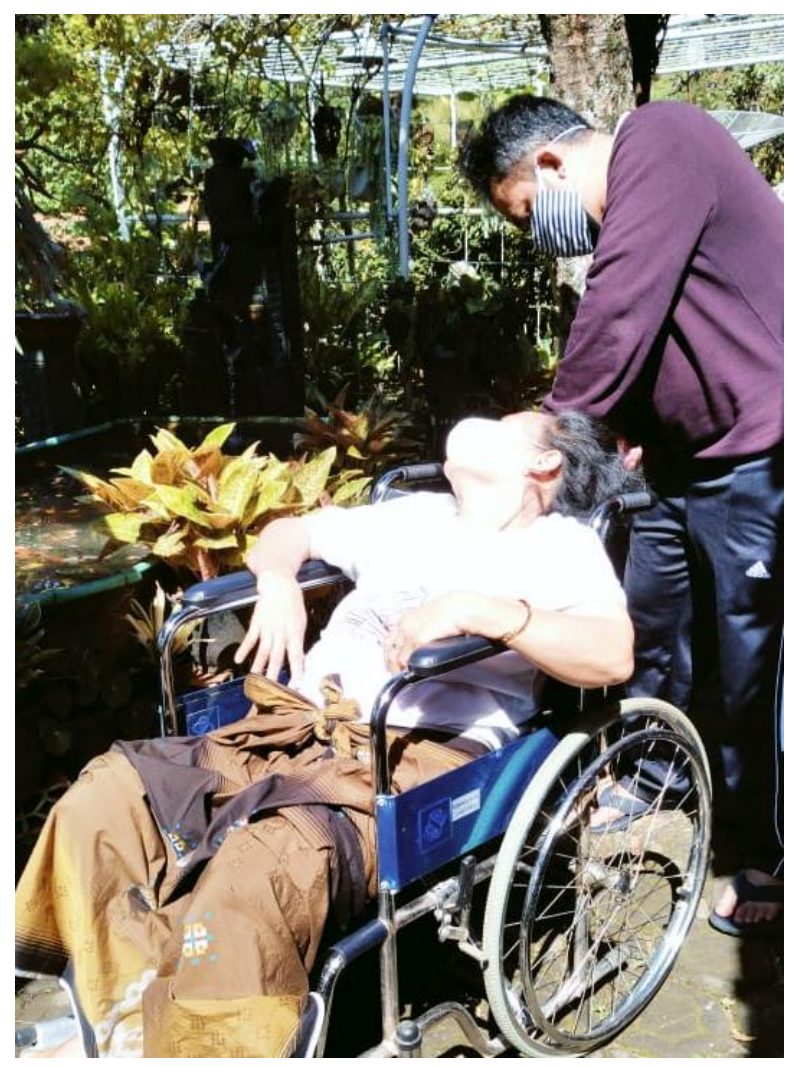

Gambar 7. Terapi dan Relaksasi

Gambar 7 merupakan abstraksi dari praktik terapi dan relaksasi sebagai agenda treatment. Agenda ini dilakukan pada waktu berjemur sinar matahari di pagi hari. Terapi dan relaksasi ini dilakukan agar penyintas Covid-19 menjadi segar dan bugar. Dengan demikian,

\section{HASIL DAN PEMBAHASAN}

Orang positif Covid-19 setelah dinyatakan negatif ternyata masih membutukan pemulihan (Syahruddin 2020). Ini bisa jadi karena faktor varian baru Covid19 bernama Delta atau karena penyintas Covid-19 merupakan lansia sebagai kelompok yang lebih rentan terhadap virus Covid-19 dibanding kaum muda (Rizaldi and Rahmasari 2021). Namun pastinya karakter virus Covid-19 bagi masingmasing orang yang terpapar ternyata dialami dengan gejala dan kondisi yang berbeda-beda.

Berdasarkan wawancara dengan orang penyintas Covid-19, memang berbeda dampak yang dirasakan antara virus yang pertama muncul dengan virus varian baru Delta. Covid yang muncul di awal-awal tidak menghilangkan selera makan sehingga asupan bisa terjaga dan dengan demikian imunitas tubuh mudah ditingkatkan. Berbeda dengan virus Covid yang muncul di awal-awal, virus varian baru Delta menghilangkan selera makan yang disertai mual ketika penderita mengkonsumsi makanan. Juga virus varian baru Delta (Lopez Bernal et al. 2021) sangat cepat menyerang organ dalam seperti jantung dan paru hingga penderita mengalami gangguan pernapasan. Varian baru Delta ini juga mengganggu persendian sehingga penderita merasakan nyeri pada otot-otot lengan tangan dan kaki. Kasus penderita Covid-19 hingga mereka tidak mampu berjalan dan harus terus berbaring. Kondisi ini terlebih lagi apa yang dialami para lansia ketika dinyatakan terpapar Covid-19.

Bukan saja kondisi fisik yang menerima dampak dari paparan Covid-19. Kenyataannya, orang mengalami tekanan mental akibat paparan Covid-19 (Purwoko and Sartinah 2021). Masyarakat merasa cemas ketika muncul pandemi Covid-19. Kecemasan juga dialami para dokter dan tenaga kesehatan pada saat menangani pasien (Widjanantie et al. 2020). Keluarga turut cemas bila ada anggota keluarga yang terpapar. Terlebih penderita pasti merasakan kecemasan yang hebat (Tobing and Wulandari 2021). Bahkan tetangga sekitar turut dihantui kecemasan. Jelas aspek mental ini menjadi salah satu problem seiring dengan darurat Covid-19.

Bermula dari kecemasan, orang terpapar Covid19 bisa mengalami depresi dan stress (Hartutik and Nurrohmah 2021). Tentu problem mental ini akan sangat mengganggu bagi pemulihan (Syahruddin 2020). Sehingga dibutuhkan terapi bagi penderita dari sisi keagamaan dan psikologi. Sisi keaagamaan (Islam) berperan sangat efektif dalam mengatasi tekanan mental melalui amalan ibadah, seperti shalat, membaca al-Qur'an, dzikir, wirid, dan do'a. Bimbingan psikologi juga berperan sangat besar untuk menumbuhkan semangat dan motivasi serta menghalau kecemasan. Terkait hal ini, terapi spiritual dengan pendekatan tasawuf sangat dibutuhkan 19 (Chodijah et al. 2020; Yono, Rusmana, and Noviyanty 2020). Ini dilakukan saat berjemur terik matahari bersamaan dengan konseling (Mexitalia et al. 2020). Terapi dilakukan terhadap 
penderita hingga menghadirkan situasi relaksasi. Selain menormalkan otot-otot dan syaraf, terapi sufistik efektif untuk membangkitkan mental spiritualitas Islam.

Jelaslah bahwa penyintas Covid-19 terutama lansia ternyata masih menghadapi masalah-masalah serius (Hartutik and Nurrohmah 2021). Melalui model pendampingan ini diperoleh kemajuan yang menggembirakan dimana ketiga orang penyintas Covid-19 tampak berangsur-angsur terus mengalami pemulihan. Hal ini menandakan bahwa model pendampingan dapat dinyatakan berhasil.

Ada beberapa indikator yang dapat menjadi alat ukur dalam melihat keberhasilan model pendampingan bagi pemulihan lansia penyintas Covid-19. Pertama, indikator kondisi normal pernafasan yang dapat diukur dengan alat saturasi oksigen. Secara berkala telah dilakukan pengecekan pada ketiga orang penyintas Covid-19 dengan hasil normal di atas angka 90. Kedua, ketiga orang lansia penyintas Covid-19 tampak berangsur pulih. Hal ini dapat ditunjukan dengan kesediaan para penyintas tanpa mengalami hambatan ketika mencerna dan mengkonsumsi makanan, meskipun masih berupa asupan yang lembut sesuai petunjuk dokter. Disebut berangsur pulih juga dilihat dari kondisi fisik penyintas yang telihat makin segar. Ketiga, para penyintas Covid-19 terlihat makin semangat untuk kembali pulih dan benar-benar sembuh. Semangat ini muncul dari motivasi dalam diri para penyintas

Pengabdian berbasis riset ini mengajukan beberapa rekomendasi. Pertama, bagi lansia penyintas Covid-19 dibutuhkan perhatian yang memadai dan intesif. Sebab, meskipun orang telah dinyatakan sembuh dalam arti negatif dari virus Covid-19, namun beberapa lanjut usia masih mengalami keluhan kondisi fisik apalagi bila mereka memiliki Riwayat penyakit penyerta. Kedua, pengendalian dan pemulihan secara bersamaan dengan pendekatan medis dan non-medis. Hal ini karena penderita bukan saja mengalami gangguan fisik, tetapi juga mengalami tekanan mental. Sehingga paduan antara medis dan non-medis dipastikan akan mempercepat proses pemulihan kesehatan. Ketiga, pentingnya partisipasi dari seluruh stakeholder yakni dokter, tenaga kesehatan Covid-19, keluarga, dan lingkungan sekitar secara bekerjasama untuk mendukung pemulihan bagi orang terpapar Covid-19.

Di atas semua itu, hal yang paling utama adalah upaya mewujudkan normal baru sebagai diharapkan pemerintah Indonesia. Sedangkan pendampingan hanyalah sebuah ikhtiyar agar semua pihak selamat dari ancaman Covid-19. Hal yang lebih berharga pasca pendampingan tentu terwujudnya kebiasaan baru dalam menerapkan pola hidup sehat. Bahkan demi terciptanya pola kebiasaan baru hidup sehat di masyarakat hingga pemerintah secara tegas menerpakan PPKM di Indonesia.

\section{KESIMPULAN}

Pengabdian ini menunjukan keberhasilan model pendampingan lansia penyintas Covid-19. Bagi orang beriman, khususnya bagi umat Islam tentu saja kesehatan merupakan anugerah Allah Swt. Akan tetapi, manusia pun harus ikhtiyar untuk menciptakan kondisi sehat. Salah satu upaya ini adalah dengan merancang model secara partisipatoris. Sehingga model ini dapat memastikan lansia penyintas Covid-19 menjadi pulih dalam hal kesehatan, baik metal maupun fisik. Kendati pun demikian, tetap upaya dari penyintas Covid-19 sendiri inilah yang paling berharga, yaitu berupa motivasi dari dalam diri penyintas Covid-19 untuk pulih, sembuh, sehat, dan selamat. Juga dukungan para pihak yang menentukan model pendampingan beroperasi sesuai harapan, yakni pihak tenaga kesehatan, keluarga besar, dan tetangga warga sekitar.

Sebagai saran dari paparan ini, hendaknya model pendampingan bagi pemulihan lansia penyintas Covid-19 terus dilakukan uji coba secara praktis. Sehingga ditemukan model pendampingan yang lebih tepat sesuai dengan konteks situasi dan kondisi. Akhirnya, semoga segenap warga masyarakat Indonesia mendapat keselamatan dalam menghadapi Covid-19.

\section{DAFTAR PUSTAKA}

Amalia, Lia, and Febriani Hiola. 2020. "Analisis Gejala Klinis Dan Peningkatan Kekebalan Tubuh Untuk Mencegah Penyakit Covid-19." Jambura Journal of Health Sciences and Research 2(2): 71-76.

Chodijah, Medina, Dian Siti Nurjannah, Ai Yeni Yuliyanti, and M Kamba. 2020. "SEFT Sebagai 
Terapi Mengatasi Kecemasan Menghadapi Covid-19." Karya Tulis Ilmiah LPPM UIN Sunan Gunung Djati Bandung.

Darmalaksana, Wahyudin. 2021. "Semangat Sembuh Dari Paparan Covid Dengan Basis Keluarga: Studi Lapangan Masa PPKM.” Kelas Menulis UIN Sunan Gunung Djati Bandung.

Hartutik, Sri, and Anjar Nurrohmah. 2021. "Gambaran Tingkat Depresi Pada Lansia Di Masa Pandemic Covid-19." Jurnal Ilmu Keperawatan Komunitas 4(1): 6-18.

Hermawan, Dessy. 2021. Manfaat Vitamin D Pada Era Pandemi Covid-19. Penerbit Andi.

Irmayani, Irmayani, Sri Melda Bangun, Anggi Isnani Parinduri, and Raisha Octavariny. 2021. "Edukasi Tentang Penerapan Protokol Kesehatan Dalam Upaya Pencegahan Covid19.” Jurnal Pengmas Kestra (JPK) 1(1): 60-63.

Lopez Bernal, Jamie et al. 2021. "Effectiveness of Covid-19 Vaccines against the B. 1.617. 2 (Delta) Variant." New England Journal of Medicine.

Mexitalia, Maria, Martvera Susilawati, Rina Pratiwi, and J C Susanto. 2020. "Vitamin D Dan Paparan Sinar Matahari Untuk Mencegah COVID-19. Fakta Atau Mitos?" Medica Hospitalia: Journal of Clinical Medicine 7(1A): 320-28.

Muhammad Tahir, A. 2020. "Nalar Agama Dan Pandemi Covid-19." In Prosiding Seminar Nasional Problematika Sosial Pandemi Covid19 "Membangun Optimisme Di Tengah Pandemi Covid-19,.

Mulyadi, Mohammad. 2020. "Partisipasi Masyarakat Dalam Penanganan Penyebaran Covid-19." Info Singkat 12(8): 13-18.

Purwoko, Budi, and Endang Pudjiastuti Sartinah. 2021. "Studi Pendekatan Terapi Psikologis Untuk Kesehatan Mental Masyarakat Pada Masa Pandemic Covid-19." TERAPUTIK: Jurnal Bimbingan dan Konseling 5(1): 141-51.

Rahmat, Abdul, and Mira Mirnawati. 2020. "Model Participation Action Research Dalam Pemberdayaan Masyarakat." Aksara: Jurnal Ilmu Pendidikan Nonformal 6(1): 62-71.

Rizaldi, Aryo Atha, and Diana Rahmasari. 2021. "Resiliensi Pada Lansia Penyintas Covid-19 Dengan Penyakit Bawaan." Universitas Negeri Surabaya.

Rosyanti, Lilin, and Indriono Hadi. 2020. "Dampak Psikologis Dalam Memberikan Perawatan Dan Layanan Kesehatan Pasien COVID-19 Pada Tenaga Profesional Kesehatan." Health Information: Jurnal Penelitian 12(1): 107-30.

Supriatna, Eman. 2020. "Wabah Corona Virus
Disease Covid 19 Dalam Pandangan Islam." SALAM: Jurnal Sosial Dan Budaya Syar-I 7(6). Suud, Fitriah M, Abdul Gaffar, Kana Safrina Rouzi, and Moh Toriqul Chaer. 2020. "The Role of Islamic Counselling in Pandemic COVID 19: A Conceptual Study for Developing Positive Emotion of Parents and Children." Jurnal Konseling Religi 11(1).

Syahruddin, Syahruddin. 2020. "Kebugaran Jasmani Bagi Lansia Saat Pandemi Covid-19." JUARA: Jurnal Olahraga 5(2): 232-39.

Tobing, CPRL, and Imanuel Sri Mei Wulandari. 2021. "Tingkat Kecemasan Bagi Lansia Yang Memiliki Penyakit Penyerta Ditengah Situasi Pandemik Covid-19 Di Kecamatan Parongpong, Bandung Barat." Community of Publishing In Nursing (COPING) 9(2): 13542.

Widjanantie, Siti Chandra et al. 2020. "Mobilisasi Tenaga Medis Dalam Menghadapi Pandemi COVID-19." Journal of The Indonesian Medical Association 70(8): 142-43.

Yono, Yono, Indriya Rusmana, and Hielda Noviyanty. 2020. "Psikoterapi Spiritual Dan Pendidikan Islam Dalam Mengatasi Dan Menghadapi Gangguan Anciety Disorder Di Saat Dan Pasca Covid 19." SALAM: Jurnal Sosial Dan Budaya Syar-I 7(7): 649-58. 